\title{
A formação acadêmica do nutricionista em saúde coletiva: um relato de experiência
}

\author{
Naiara Sperandio, Flávia Farias Lima, Rute Costa, Camilla Medeiros Macedo da Rocha, Márcia \\ Regina Viana, Tamiris Rizzo
}

\section{Resumo}

Os desafios envolvidos com a formação do profissional nutricionista em saúde coletiva, ocupa papel relevante em sua trajetória acadêmica, visto a atual realidade de saúde da população brasileira, que exige um profissional generalista que considere a complexidade desse cenário, e que esteja pronto para atender as demandas individuais e coletivas. Sendo assim, é imperativo que as instituições acadêmicas repensem suas práticas de ensino, para de fato contribuir com o fortalecimento do Sistema Único de Saúde (SUS), dentro de uma perspectiva do atendimento integral e humanizado, em equipes multidisciplinares. Relatar como uma disciplina do curso de graduação em Nutrição, da Universidade Federal do Rio de Janeiro (UFRJ), campus Macaé, busca iniciar a formação dos estudantes em nutrição, atendendo as recomendações presentes no Consenso sobre Habilidades e Competências do Nutricionista no âmbito da Saúde Coletiva. Trata-se de um relato de experiência da disciplina "Saúde da Comunidade I" oferecida aos estudantes de primeiro período do curso de Nutrição da UFRJ. Para construção deste trabalho utilizou-se como referência o consenso sobre as competências e habilidades necessárias ao profissional de saúde coletiva, publicado em 2013 pelo Observatório de Políticas e Segurança Alimentar e Nutrição (OPSAN). A disciplina "Saúde da Comunidade I" possui carga horária majoritariamente prática e envolve campos de atuação da atenção básica, como a Estratégia de Saúde da Família (ESF), e da proteção básica, como o Centro de Referência da Assistência Social (CRAS), do município de Macaé. Os principais aspectos abordados nos campos práticos são: território, população adstrita, ações desenvolvidas pelos serviços, trabalho em equipe, educação popular em saúde, e visitas domiciliares. A vivência dos alunos nesses serviços, possibilita que os mesmos se aproximem da realidade e conheçam as demandas, potencialidades e dificuldades do trabalho em equipe nos serviços. De acordo com o consenso, deve-se estimular a inserção dos alunos de graduação em campos práticos, o mais precocemente possível durante o curso, para construção de conhecimento e para integração serviço-ensino. Diante disso, a disciplina pauta-se em uma abordagem pedagógica inovadora, crítica, que busca, aliada a demais disciplinas do curso, formar estudantes capazes de prestar atendimento integral e humanizado, de trabalhar em equipe, e de atender demandas individuais e coletivas do território no qual estarão inseridos. Disciplinas, como a Saúde da Comunidade I, aqui apresentada, buscam reparar lacunas entre a formação do aluno e o perfil de competências necessárias para atuação no SUS. O consenso sobre as habilidades e competências do nutricionista para saúde coletiva é referência importante a ser analisada pelos docentes, para que suas recomendações sejam contempladas nos cursos, a fim de que de fato se possa formar um profissional generalista, dentro de uma perspectiva mais complexa e humanizada e menos biologicista, e que fomente no profissional a vontade de "ser mais".

Descritores: Educação Alimentar e Nutricional; Educação Popular; Formação do nutricionista; Saúde Coletiva; Educação em saúde. 